\title{
Phomopsis stem canker of sunflower in North America: correlation with climate and solutions through breeding

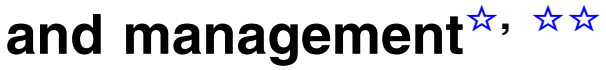

\author{
Brent S. Hulke ${ }^{1, *}$, Samuel G. Markell ${ }^{2}$, Nolan C. Kane ${ }^{3}$ and Febina M. Mathew ${ }^{4}$ \\ ${ }^{1}$ USDA-Agricultural Research Service, Edward T. Schafer Agricultural Research Center, Fargo, ND, USA \\ 2 North Dakota State University, Department of Plant Pathology, Fargo, ND, USA \\ ${ }^{3}$ University of Colorado, Department of Ecology and Evolutionary Biology, Boulder, CO, USA \\ ${ }^{4}$ South Dakota State University, Department of Agronomy, Horticulture, and Plant Science, Brookings, SD, USA
}

Received 19 February 2019 - Accepted 4 March 2019

\begin{abstract}
Climate change is occurring in the central US and is interacting with agroecological factors to increase biotic stress in sunflower. Certain species of Diaporthe cause Phomopsis stem canker in sunflower and other dicotyledonous weeds and crops. The increase in precipitation already observed in the states of North Dakota, South Dakota, and Minnesota have increased the chances of outbreaks of necrotrophic pathogens, like Diaporthe. We discuss how climate trends, combined with technological, management, and economic interactions, are correlated with increasing incidence of Phomopsis stem canker in these and adjacent areas in North America. Further, we discuss management options and the role of improved sunflower genetics in reducing Phomopsis stem canker outbreak risk.
\end{abstract}

Keywords: Sunflower and Climate Change Symposium / Helianthus annuus / Diaporthe / Phomopsis / yield

Résumé - Le Phomopsis du tournesol en Amérique du Nord : corrélation avec le climat et solutions par amélioration génétique et gestion agronomique. Le changement climatique se fait sentir dans le centre des États-Unis et interagit avec des facteurs agroécologiques pour augmenter le stress biotique du tournesol. Certaines espèces de Diaporthe provoquent des attaques de Phomopsis chez le tournesol ainsi que d'autres espèces dicotylédones, cultivées ou adventices. L'augmentation des précipitations déjà observée dans les États du Dakota du Nord, du Dakota du Sud et du Minnesota a accru les risques d'épidémies de pathogènes nécrotrophes, tels que Diaporthe. Nous discutons de la façon dont les tendances climatiques, associées aux interactions technologiques, agronomiques et économiques, sont corrélées à l'incidence croissante de Phomopsis dans ces zones et les zones adjacentes en Amérique du Nord. De plus, nous discutons des options de gestion et du rôle de l'amélioration génétique du tournesol dans la réduction du risque d'épidémies de Phomopsis.

Mots clés : Symposium Sunflower and Climate Change / Helianthus annuus / Diaporthe / Phomopsis / rendement

The Sunflower and Climate Change Symposium gathered sunflower researchers from around the world to discuss how climate has shaped or will shape sunflower production in their regions and develop strategic research agendas to counteract

\footnotetext{
Contribution to the Topical Issue "Sunflower and climate change / Tournesol et changement climatique"

से Mention of trade names or commercial products in this article is solely for the purpose of providing specific information and does not imply recommendation or endorsement by the U.S. Department of Agriculture.

*Correspondence: brent.hulke@ars . usda.gov
}

negative effects of changing climate on our crops. In North America, changes in climate have shaped or interacted with land use, technology, and management changes over time to result in new challenges to sunflower production. Our case study centers on a biotic stress challenge: the increase in incidence of Phomopsis stem canker (caused by species of Diaporthe).

\section{Climate change: interactions with producer decision-making and agroecology}

One way we monitor climate in real time is through evaluation of changes in yearly averages. In the United States, 

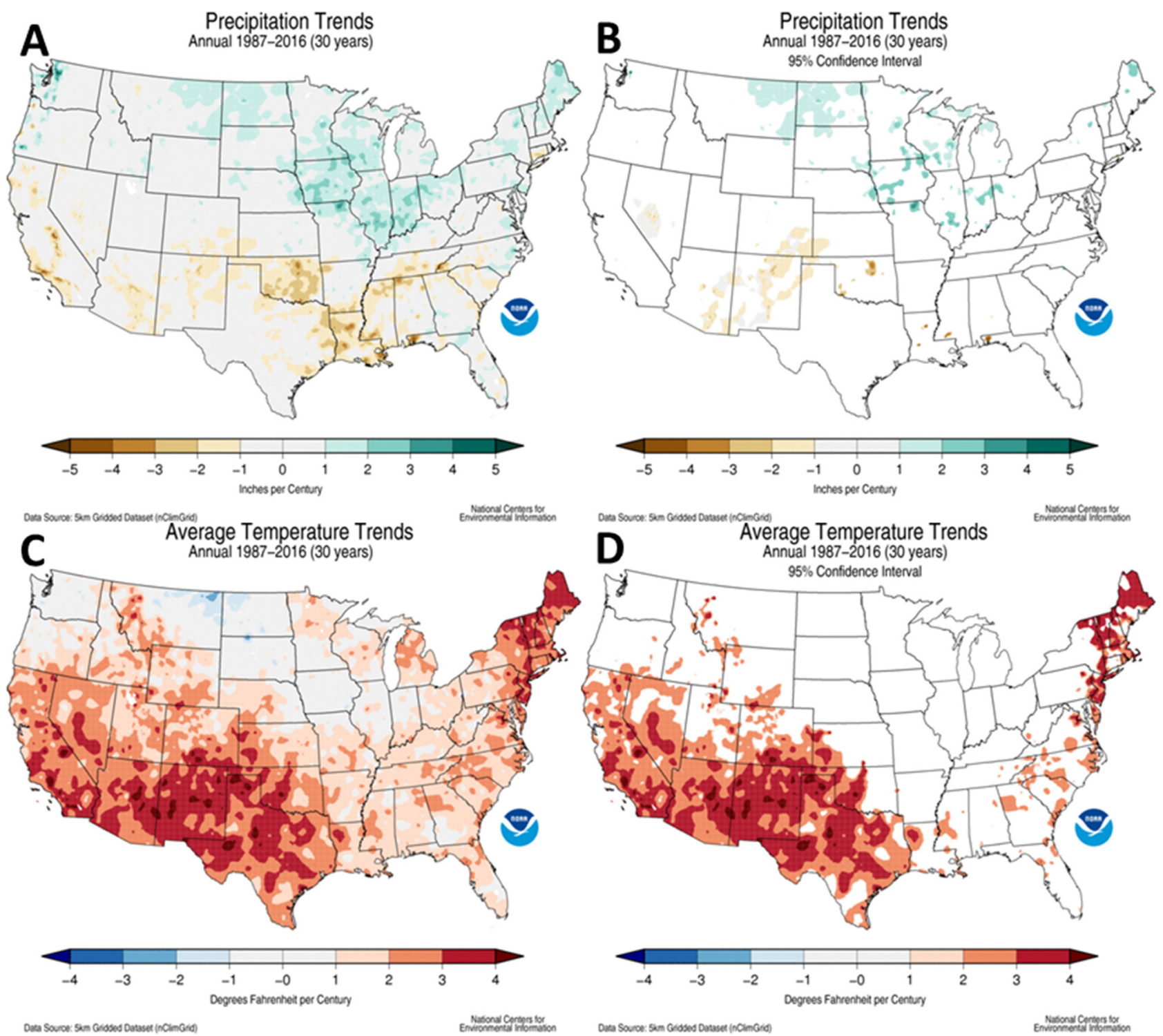

Fig. 1. Annual precipitation and temperature trends for the 30 -year period of 1987 to 2016 . 1 inch=25.4 mm and 1 Fahrenheit degree $=0.56$ Celsius degree. (A) Overall trends for precipitation, (B) trends for precipitation that are a significant departure from initial values for the period at the $95 \%$ statistical confidence level, (C) overall trends in temperature, and (D) trends for temperature that are a significant departure from initial values for the period at the $95 \%$ statistical confidence level. Figures available from NOAA-NCEI (2018).

a database has been assembled that allows us to evaluate these changes graphically, with statistical support (e.g. Fig. 1; NOAA-NCEI, 2018). In the past three decades, climate has trended significantly wetter in the north central states, a major sunflower growing region, while it has trended significantly hotter in the southern sunflower growing region of Colorado, Kansas, and Texas (Fig. 1). Southeast Colorado and adjacent areas have turned significantly drier, as well. Some warming has occurred over this period in parts of the north central states, that while not statistically significant in this analysis, has resulted in changes in temperature extremes. These developments have led the U.S. Department of Agriculture to update its Plant Hardiness Zone Maps (USDA-ARS, 2018).

These changes in climate have combined with other factors to change land use in the north central US and eastern prairie provinces in Canada. Advances in soybean breeding resulted in the development of early maturing soybean varieties that are tolerant of colder climates (e.g. Helms and Nelson, 2015), the need for which is partially offset by more favorable climate. The acceptance by producers of adapted soybean varieties is also driven by favorable production systems, such as Roundup Ready ${ }^{\circledR}$ technology (glyphosate herbicide tolerance), which has simplified weed control dramatically. An increase in exports, particularly to China, has allowed soybean prices to remain high over much of the last two decades, despite an increasing land area devoted to the crop and increasing yields due to improved genetics and agronomy (Gale et al., 2015; USDA-NASS, 2019). As soybean hectares increase, the area of other crops has decreased, including sunflower (Fig. 2).

Changes in climate have not been as favorable to sunflower as it has been to other crops in the north central US. Sunflower can be susceptible to diseases caused by necrotrophic pathogens 


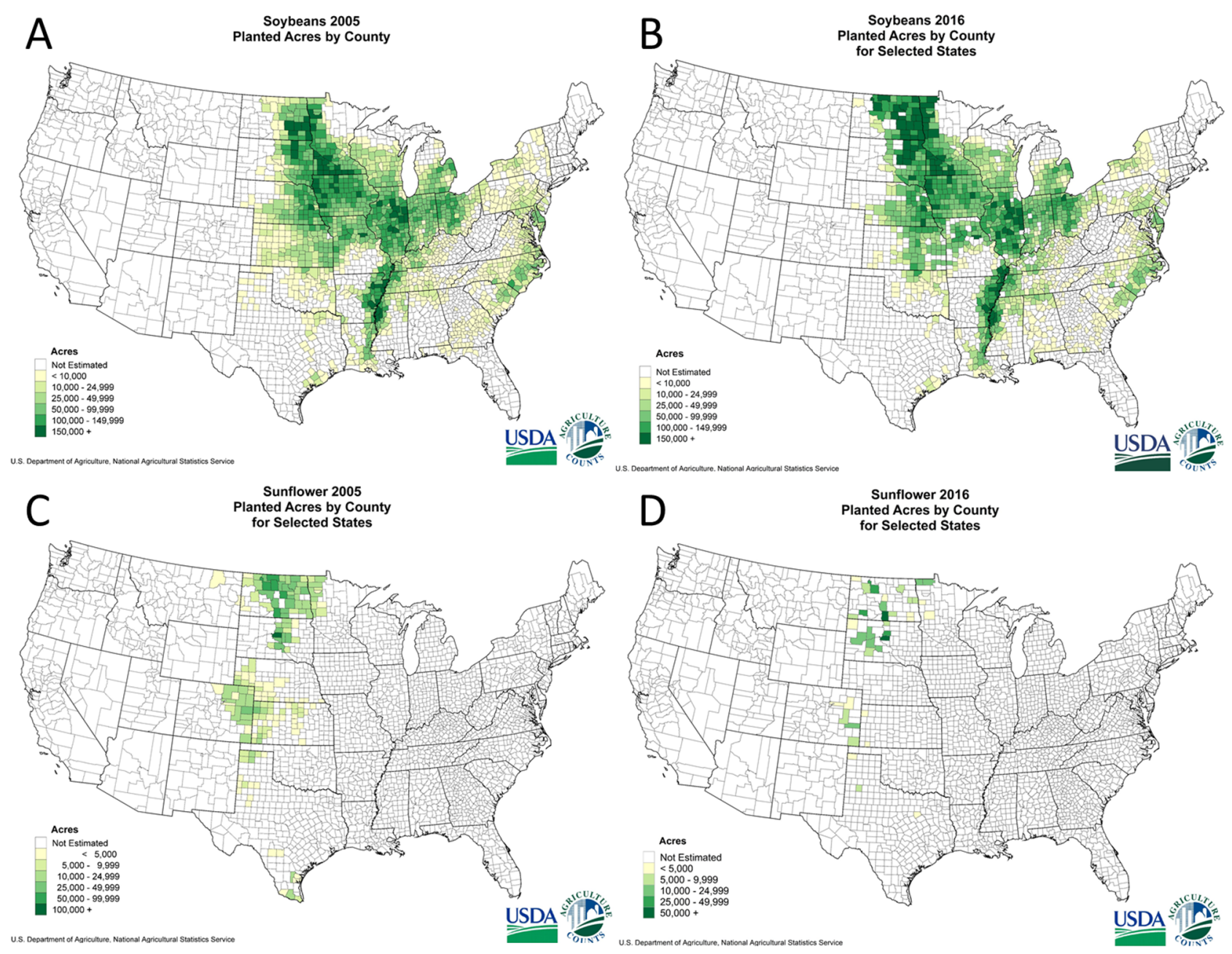

Fig. 2. Production area shifts for soybeans and sunflower 2005-2016, represented as acres per county. 1 acre $=0.4$ ha. Note that color scale differs by year and commodity. (A) Soybeans 2005, (B) soybeans 2016, (C) sunflower 2005, and (D) sunflower 2016.

under humid conditions in late summer (Gulya et al., 1997). One of these, Phomopsis stem canker, has increased in incidence over the previous two decades, as captured in the National Sunflower Association (USA) Sunflower Survey data (Fig. 3; Gulya et al., 2019). A gradual upward trend has been seen in the percentage of sunflower fields infested with the disease, broken only by brief interludes of drought.

Despite sunflower being native to North America and cultivated for thousands of years by Native Americans (Heiser, 1951), the first report of Phomopsis stem canker of sunflower occurred in the former Yugoslav republics in 1980. Sporadic outbreaks occurred in the USA shortly after the Yugoslav reports (Masirevic and Gulya, 1992), but the disease had not received much notice by agronomists and plant breeders in the US until around 2010 (Mathew et al., 2015; Gulya et al., 2019). The disease is maintained in decomposing plant litter in the soil and can be seed transmitted. Spores from the fungal perithecia can be spread by wind and rain over short distances, and inoculum can build up over years under ideal environmental conditions in a given area. Crop rotation strategies to counteract inoculum buildup are difficult to implement because nearby fields are often sources of inoculum (Masirevic and Gulya, 1992).

Sunflower is not the only crop to be affected by Phomopsis stem canker, as it can infest many dicotyledonous weed and crop plants. However, there are a large number of species in the Diaporthe genus and different species have been isolated from different crops, suggesting specialization by the pathogen. Until recently, it was believed that only Diaporthe helianthi Muntañola-Cvetkovic, Mihaljcevic, and Petrov was pathogenic to sunflower, but recent investigations have also isolated at least ten other species of Diaporthe from sunflower, including D. gulyae Shivas, Thompson and Young (Thompson et al., 2011, 2015; Mathew et al., 2015). In 2017, D. stewartii Harrison was found to infect sunflower in Polk County, Minnesota (Olson et al., 2017). Recently, D. gulyae was also isolated from soybean in North Dakota and South Dakota, in regions where both sunflower and soybean are grown (Mathew et al., 2018; Gilley et al., 2019). This expands the land area producing inoculum for this pathogen greatly, and may explain, in part, the recent increases in incidence in sunflower (Fig. 3; Gulya et al., 2019). 


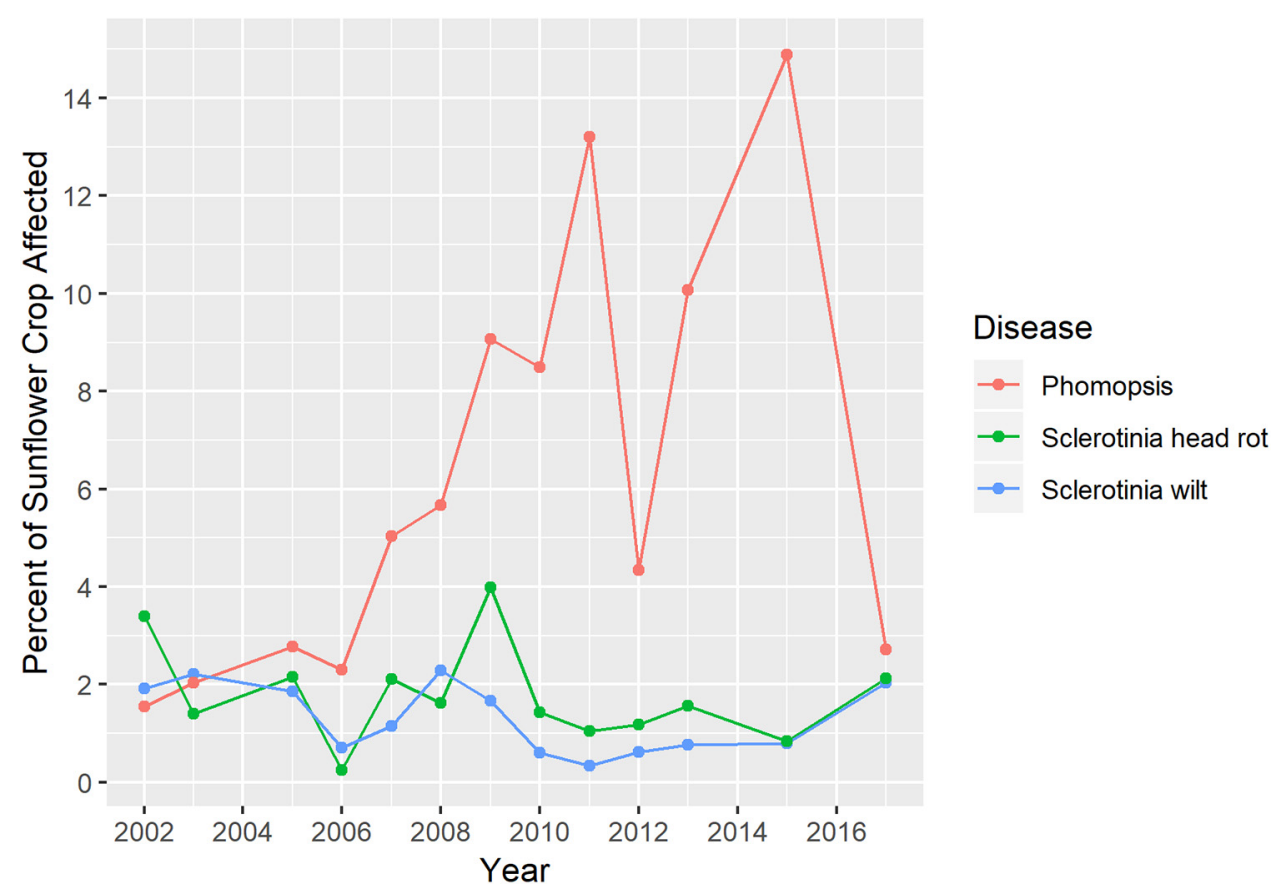

Fig. 3. Percentage of sunflower crop affected by three necrotrophic diseases, Phomopsis (caused by Diaporthe spp.), and Sclerotinia head rot and Sclerotinia wilt/basal stem rot (caused by Sclerotinia sclerotiorum). The percentage was calculated by multiplying the percentage of fields with each disease by the average within-field percent incidence excluding unaffected fields, from survey data across North America. Data from National Sunflower Association (2018) and calculations from Gulya et al. (2019).

It is noteworthy to mention that another major necrotrophic pathogen is common to both soybean and sunflower, Sclerotinia sclerotiorum (Lib.) de Bary. This pathogen causes three diseases in sunflower, a basal stem rot/wilt through direct mycelial penetration of roots, and a mid-stem and head rot caused by airborne ascospores (Gulya et al., 1997). In soybean, only ascospore infection of flowers has been observed (Bolton et al., 2006). Diaporthe- and Sclerotinia-associated diseases are favored under conditions of frequent rainfall or free moisture, with a temperature optimum about $25^{\circ} \mathrm{C}$ (Gulya et al., 1997). Despite the similarities in environmental suitability, unlike Phomopsis, Sclerotinia has been a notorious disease of sunflower, soybean, and other crops in North America for a long time, and efforts such as the National Sclerotinia Initiative (USA) and private breeding have reduced the genetic susceptibility of these crops to Sclerotinia sclerotiorum. This is evident in Figure 3 by the low incidence of Sclerotinia associated disease over the last decade. In contrast, cultural and genetic efforts to manage Phomopsis stem canker in North American sunflower have only begun circa the last 10 years, and lack of immediate genetic progress across current commercial hybrids contributes to increased incidence under favorable conditions (Fig. 3; Gulya et al., 2019). In soybean, Diaporthe-associated diseases have received attention from researchers (Backman et al., 1985), but there is little information available on the resistance genes currently deployed in commercial soybean cultivars.

An additional contributing factor to increased Phomopsis incidence in sunflower is failure of the Roundup Ready glyphosate-tolerance system to control some species of weeds that also host species of Diaporthe. Glyphosate tolerance in kochia (Kochia scoparia L.) has already developed in North Dakota and South Dakota, which is a concern because very few other chemistries control this weed effectively (Heap, 2018). Recently, Ghimire et al. (2018) isolated D. gulyae from kochia and lambsquarters (Chenopodium album L.) and showed that the weed-derived isolates could infect sunflower. Since North Dakota and South Dakota are among the states where Phomopsis stem canker of sunflower is the most prevalent, the additional reservoir of inoculum from a difficult-to-control, common weed that is present in many different types of crops may be contributing to inoculum availability.

\section{Management of Phomopsis under our current climate conditions}

Perhaps one of the easiest means of controlling fungal diseases is through application of fungicides. Experimental trials to control Phomopsis with fungicides have thus far not provided a simple solution for producers, mainly because the timing of fungicide treatment must coincide with the conditions most favorable for development of the disease. This may necessitate fungicide treatment many times a season and under conditions that are not favorable for aerial application of fungicide (Samuel Markell, pers. comm., 2018). Despite these difficulties, research is underway to develop disease prediction models, as well as rate and timing recommendations, that could assist sunflower producers in attempts to treat fields with fungicides.

The recent findings of Ghimire et al. (2018) underline the importance of weed control in managing this disease. Beyond the yield impacts caused by weed presence in fields, their role 
Table 1. Performance of new USDA Phomopsis-resistant sunflower inbred line releases as testcrosses, compared to those of previously released USDA lines and commercial hybrids adapted to North America, four environments, 2011-2016.

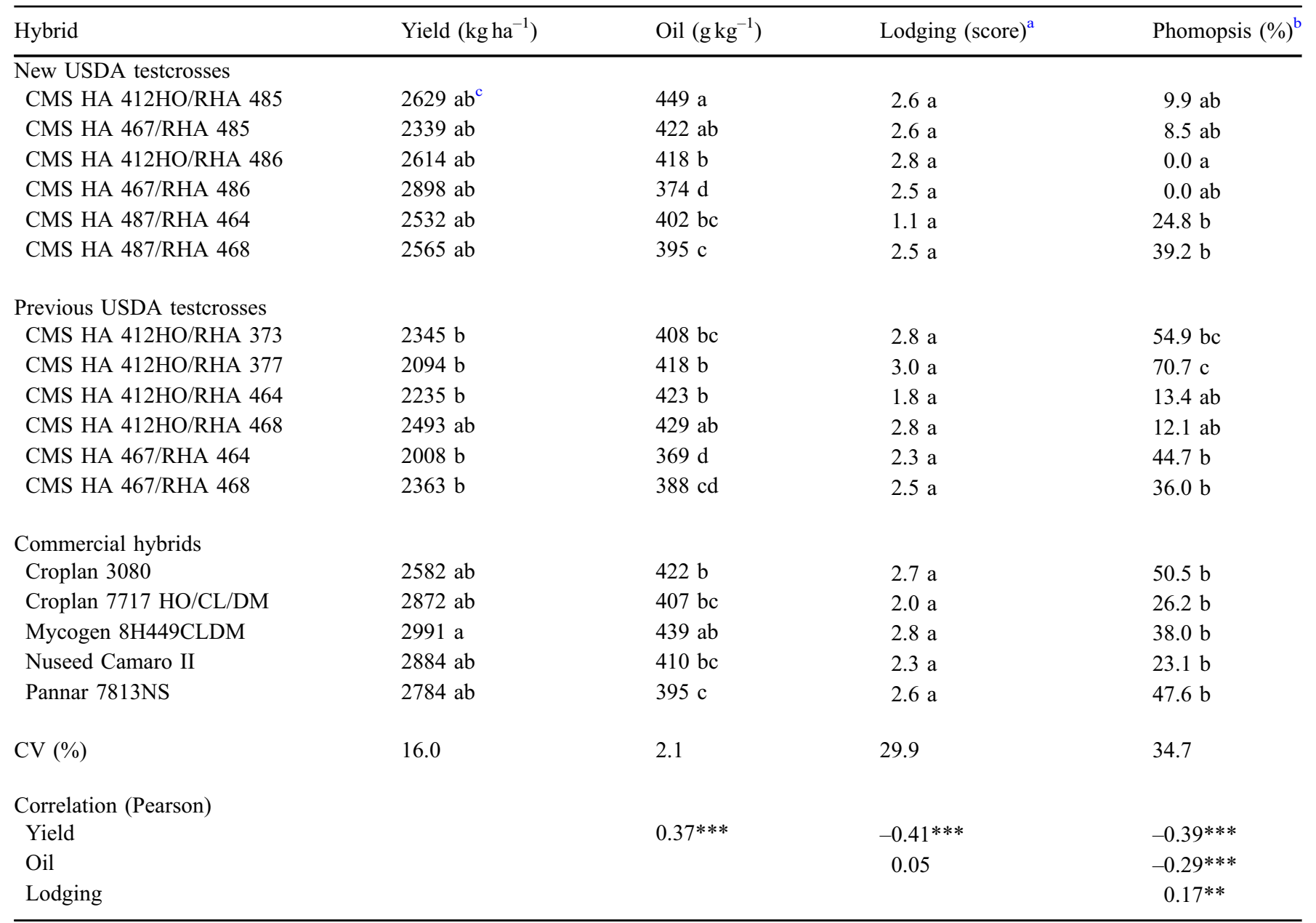

${ }^{\text {a }}$ Lodging was scored on a 1 to 9 scale with 1 indicating no lodged or leaning plants, 9 indicating all plants completely lodged. Hybrids with the highest and lowest lodging scores were significant at $p=0.06$.

${ }^{\mathrm{b}}$ Heavy, natural infestation at all four environments. Diseased plots were used for yield data.

${ }^{\mathrm{c}}$ Common non-superscript letters denote hybrids that are not significantly different at the $p<0.05$ level.

$* *, * * *$ Significant at the 0.01 and 0.001 probability levels, respectively.

in spreading the Diaporthe pathogen further increases the importance of good weed control in sunflower fields and adjacent areas. With glyphosate no longer an effective weed control tool for many glyphosate-tolerant crops, use of other effective herbicide classes, such as pre-emerge chemistries in combination with pre-plant burndown treatments, a few postemergence herbicides such as dicamba or fluroxypyr (in monocot crops), tillage, or perhaps, new weed control technologies are needed to reduce this important risk factor for disease development (Lawrence and Creech, 2016; Thompson, 2018).

As is often the case with necrotrophic pathogens, hostplant resistance can be a useful way to reduce disease, but the complex inheritance that underlies the resistance phenotype can be a barrier to balanced breeding for yield and quality. Recent work by Talukder et al. (2014) showed that in North Dakota, South Dakota, and Minnesota, resistance to $D$. helianthi (natural field incidence with pathogen confirmed in a laboratory assay) had very low genotype-by-environment interaction and high broad-sense heritability. It also had a moderate broad-sense genetic correlation with Sclerotinia head rot resistance $(r=0.45)$. However, recent mapping work has indicated that the resistance phenotype is quantitative, due to a few large effect loci and many moderate- to small-effect loci that exist in genomic clusters (Viguié et al., 2000; Bert et al., 2002; Brent Hulke and Nolan Kane, in preparation, 2019). Recent breeding progress has resulted in parental lines with good resistance without much assistance from genomics-assisted methods. However, the yields of the most resistant materials do not consistently surpass that of high-yielding, more susceptible commercial hybrids (Tab. 1). Yield can be affected by Phomopsis in two ways, first by premature ripening of the seeds and second by lodging of diseased stems, while oil content is only affected by premature ripening. In the experiment described in Table 1, most of the damage was from premature ripening, with little damage from lodging. If autumn weather conditions favored lodging 
in that experiment, further losses would have occurred in the susceptible commercial hybrids. Nonetheless, the use of genomics in breeding to optimize yield increases with disease resistance will be an important goal, since a successful commercial hybrid must do well both under disease pressure and without disease.

\section{Conclusions}

Producer decision-making has already been changing (either actively or passively) to the changes in climate already observed. Compounding the effects of climate change, technological innovations, changing management recommendations, economic developments, and the interactions thereof, can provide us certainty that our agricultural landscapes will continue to change in the upcoming decades. The Intergovernmental Panel on Climate Change report (Hoegh-Guldberg et al., 2018) predicts that at 1.5 to $2.0^{\circ} \mathrm{C}$ of average global warming, the central US will see further increases in heavy precipitation events, an overall increase in precipitation, and increases in consecutive dry days. This suggests that precipitation could occur in high intensity periods with intervening drought periods, resulting in an overall increase in average precipitation. Similar trends are expected in Northern and Central Europe. Under these potential scenarios, crop production systems will need to be resilient to rapidly changing weather patterns and the crops themselves adapted to stresses caused by extremes in weather which are rarely observed today. Sunflower has the potential to be a key oilseed crop because it is adaptable to a wide range of conditions, but it can be improved to be a better player in crop rotations of the future. Susceptibility to necrotrophic pathogens such as Diaporthe is a weakness, and proactive research to mitigate diseases in a changing climate is critical. Innovations in genetics research through optimization of yield and disease resistance will make sunflower better adapted to scenarios that are expected to be more common in the future.

\section{References}

Backman PA, Weaver DB, Morgan-Jones G. 1985. Soybean stem canker: An emerging disease problem. Plant Dis 69: 641-648.

Bert PF, Jouan I, de Labrouhe DT, Serre F, Nicolas P, Vear F. 2002. Comparative genetic analysis of quantitative traits in sunflower (Helianthus annuus L.) 1. QTL involved in resistance to Sclerotinia sclerotiorum and Diaporthe helianthi. Theor Appl Genet 105: 985-993.

Bolton MD, Thomma BP, Nelson BD. 2006. Sclerotinia sclerotiorum(Lib.) de Bary: Biology and molecular traits of a cosmopolitan pathogen. Mol Plant Pathol 7: 1-16.

Gale F, Hansen J, Jewison M. 2015. China's growing demand for agricultural imports. Economic information bulletin number 136. Washington DC, USA: USDA-Economic Research Service.

Ghimire K, Kontz B, Markell S, Mathew F. 2018. Weeds as source of inoculum of Diaporthe gulyae, the causal agent of Phomopsis stem canker of sunflower (Poster). Proceedings of the 9th International Integrated Pest Management Symposium, Baltimore, MD. March 19-22, 2018.
Gilley M, Kontz B, Mathew F, Markell S. 2019. Identification of crop and weed species as possible hosts to the pathogens causing Phomopsis stem canker on sunflower. Proceedings of the 41th Annual Sunflower Research Forum, Fargo, ND. January 9-10, 2019 (Poster).

Gulya T, Rashid KY, Masirevic SN. 1997. Sunflower diseases. In: Schneiter AA, ed. Sunflower technology and production, agronomy monograph 35. Madison, WI, USA: American Society of Agronomy, pp. 263-379.

Gulya TJ, Harveson RM, Mathew FM, et al. 2019. Comprehensive disease survey of US sunflower: Disease trends, research priorities and unanticipated impacts. Plant Dis. DOI: 10.1094/ PDIS-06-18-0980-FE.

Heap I. 2018. The international survey of herbicide resistant weeds. Available at http://www.weedscience.com (accessed 20 December 2018).

Heiser C. 1951. The sunflower among the North American Indians. Proc Am Philos Soc 95: 432-448.

Helms TC, Nelson BD. 2015. Registration of "ND Henson" soybean. J Plant Regist 10: 10-13.

Hoegh-Guldberg O, Jacob D, Taylor M, et al. 2018. Impacts of $1.5^{\circ} \mathrm{C}$ global warming on natural and human systems. In: MassonDelmotte V, Zhai P, Pörtner HO, Roberts D, Skea J, Shukla PR, Pirani A, Moufouma-Okia W, Péan C, Pidcock R, Connors S, Matthews JBR, Chen Y, Zhou X, Gomis MI, Lonnoy E, Maycock $\mathrm{T}$, Tignor M, Waterfield T, eds. In: Global warming of $1.5^{\circ} \mathrm{C}$. An IPCC Special Report on the impacts of global warming of $1.5^{\circ} \mathrm{C}$ above pre-industrial levels and related global greenhouse gas emission pathways, in the context of strengthening the global response to the threat of climate change, sustainable development, and efforts to eradicate poverty. In Press.

Lawrence N, Creech C. 2016. Managing glyphosate- and ALSresistant kochia in the Panhandle. Available at https://cropwatch. unl.edu/2016/managing-glyphosate-and-als-resistant-kochia-pan handle (accessed 20 December 2018).

Masirevic S, Gulya TJ. 1992. Sclerotinia and Phomopsis-two devastating sunflower pathogens. Field Crops Res 30: 271-300.

Mathew F, Alananbeh KM, Jordahl JG. 2015. Phomopsis stem canker: A re-emerging threat to sunflowers (Helianthus annuus) in the United States. Phytopathology 105: 990-997.

Mathew FM, Gulya TJ, Jordahl JG, Markell SG. 2018. First report of stem disease of soybean (Glycine max) caused by Diaporthe gulyae in North Dakota. Plant Dis 102: 240.

National Sunflower Association. 2018. Sunflower crop survey. Available at http://www.sunflowernsa.com/growers/yield-andsurvey/sunflower-crop-survey/ (accessed 15 January 2018).

NOAA-NCEI. 2018. Climate montoring-national trends. Available at https://www.ncdc.noaa.gov/temp-and-precip/us-trends/ (accessed 15 January 2018).

Olson T, Kontz B, Markell S, Gulya T, Mathew F. 2017. First report of Diaporthe stewartii causing Phomopsis stem canker of sunflower (Helianthus annuus) in Minnesota. Plant Dis 101: 382.

Thompson C. 2018. Kochia control. Available at https://www. sunflower.k-state.edu/agronomy/weed_control/kochia_control. html (accessed 20 December 2018).

Thompson SM, Tan YP, Young AJ, Neate SM, Aitken EAB, Shivas RG. 2011. Stem cankers on sunflower (Helianthus annuus) in Australia reveal a complex of pathogenic Diaporthe (Phomopsis) species. Persoonia 27: 80-89.

Thompson SM, Tan YP, Shivas RG, et al. 2015. Green and brown bridges between weeds and crops reveal novel Diaporthe species in Australia. Persoonia 35: 39-49. 
Talukder ZI, Hulke BS, Marek L, Gulya TJ. 2014. Sources of resistance to sunflower diseases in a global collection of domesticated USDA plant introductions. Crop Sci 54: 694-705.

USDA-ARS. 2018. USDA Plant Hardiness Zone map. Available at https://planthardiness.ars.usda.gov/PHZMWeb/Default.aspx (accessed 15 January 2018).
USDA-NASS. 2019. Quick stats tools. Available at https://www.nass. usda.gov/Quick_Stats/index.php (Accessed 10 February 2019).

Viguié A, de Labrouhe DT, Vear F. 2000. Inheritance of several sources of resistance to Phomopsis stem canker (Diaporthe helianthi Munt.-Cvet.) in sunflower (Helianthus annuus L.). Euphytica 116: 167-179.

Cite this article as: Hulke BS, Markell SG, Kane NC, Mathew FM. 2019. Phomopsis stem canker of sunflower in North America: correlation with climate and solutions through breeding and management. OCL 26: 13 . 